\title{
Chapter 14 \\ In Vitro Models for Methylmercury \\ Neurotoxicity: Effects on Glutamatergic \\ Cerebellar Granule Neurons
}

\author{
Cristina Suñol and Eduard Rodríguez-Farré
}

\begin{abstract}
Methylmercury ( $\mathrm{MeHg}$ ), a relevant persistent environmental contaminant, is widely recognized as a potent neurotoxicant in humans. The clinical features of $\mathrm{MeHg}$-intoxicated people are characterized by neurological dysfunction that induces cerebellar-based ataxia, generalized extremity weakness, and sensory disturbances including speech, vision, and hearing impairment, which correlate with the loss of neurons from several areas of the brain, among them the cerebellar granule cell (CGC) layer. CGCs are glutamatergic neurons that are successfully grown in vitro. Here, we report the effects of short and long term exposure to MeHg on primary cultures of CGCs. Short exposure to micromolar concentrations of MeHg inhibits neuronal glutamate uptake and induces the release of endogenous glutamate, the increase of intracellular calcium and of oxidative stress. After continuous exposure to low $\mathrm{MeHg}$ concentration (in the nanomolar range) oxidative stress results in lipid peroxidation and cell death which are reduced by the glutathione peroxidase (GPx)enhancing antioxidant probucol or by overexpressing GPx in the cells. Decreased phosphorylation and translocation of cofilin from the cytosol to the mitochondria are also early hallmarks of $\mathrm{MeHg}$-induced toxicity in cultured cerebellar granule neurons.
\end{abstract}

\section{Introduction}

Methylmercury ( $\mathrm{MeHg})$, a relevant persistent environmental contaminant, is widely recognized as a potent neurotoxicant in humans (Castoldi et al. 2003; Grandjean and Landrigan 2006; Grandjean 2007) that affects both the developing and mature

\footnotetext{
C. Suñol $(\square) \bullet$ E. Rodríguez-Farré

Institut d'Investigacions Biomèdiques de Barcelona, CSIC-IDIBAPS,

Rosselló 161, 08036, Barcelona, Spain

e-mail: csenqi@iibb.csic.es
} 
central nervous system (CNS). Based on two epidemics of $\mathrm{MeHg}$ poisoning (Minamata Bay, Japan and Iraq) and on recent prospective studies on general population, ingestion of contaminated food can be considered as the primary route of exposure (Grandjean 2007; Ramón et al. 2008). Observational studies of individuals exposed early in life in Minamata, where inorganic mercury was discharged in waste water from a chemical plant and biotransformed to $\mathrm{MeHg}$ by sea organisms and biomagnified through the trophic chain, have shown that both developmental and aging states exacerbated the neurotoxic effects of this organometal, with primary signs of neurological dysfunction such as cerebellar ataxia, visual impairment, weakness of extremities, and sensory disturbances (Eto et al. 2010; Ekino et al. 2007; Murata et al. 2007). Psychiatric effects have also been related to MeHg exposures in Minamata (Yorifuji et al. 2011). The most susceptible regions to $\mathrm{MeHg}$ mediated injury are the brain cortex and the cerebellum, with high selectivity in cerebellar granule cells (CGCs). Granule cells in the cerebellum refer to a type of small neurons (usually $10 \mu \mathrm{m}$ ) located in the most inner layer of the cerebellar cortex. They are the most abundant neurons in the CNS. CGCs are glutamatergic and therefore exert excitatory effects on their targets while they receive excitatory input from mossy fibers and inhibitory input from Golgi cells.

Clinically, MeHg-intoxicated people are characterized by a neurological dysfunction that induces cerebellar-based ataxia, generalized extremity weakness, and sensory disturbances including speech, vision, and hearing impairment (Clarkson et al. 2003; Sanfeliu et al. 2003; Ekino et al. 2007; Murata et al. 2007). All these effects correlate with the loss of neurons from several areas of the brain, among them the CGC layer (Korogi et al. 1998; Ekino et al. 2007; Eto et al. 2010). In addition to cerebellar neurodegeneration, abnormal migration of neurons in the cerebellum and microtubule formation deficits were observed during fetal neural development and in affected newborn babies (Choi et al. 1978; Castoldi et al. 2000).

Neurotoxicity is the consequence of the failure of one or multiple molecular mechanisms, such as the functioning of ion channels (voltage-dependent or ligand operated receptors such as ionotropic $\mathrm{GABA}_{\mathrm{A}}$, glutamate NMDA and AMPA/kainate, and nicotinic acetylcholine receptors), the synthesis, degradation and transport of neurotransmitters, the control and regulation of cell status (energy status, mitochondrial and plasma membrane potential, intracellular ion homeostasis, generation and inactivation of reactive oxygen species (ROS), maintenance and dynamics of the cytoskeleton). The mechanisms of $\mathrm{MeHg}$ neurotoxicity have not yet been fully elucidated. However, a lot of studies have provided several putative mechanisms involving oxidative stress, amino acid transport, calcium homeostasis, neurotransmitter receptors, and microtubule dynamics, among others.

In vitro techniques based on cellular cultures have been developed and used for the study of specific questions of neurobiology and cellular biology. These in vitro methods have also been successfully used to evaluate the neurotoxic effects of chemical substances and to study the underlying mechanisms of neurotoxicity. This way, the identification of toxicity pathways of neurotoxicity by means of in vitro mechanistic studies is in line with the US National Academy of Sciences recommendations on toxicity testing in the twenty-first century (2007), which indicates that test 
assays based on mechanisms are central components of the overall strategies of toxicity testing in assessing biological activity of new and existing compounds.

Primary cultures of CGCs are constituted $>95 \%$ of glutamatergic neurons that express receptors for glutamate and GABA (Suñol et al. 2008). They are prepared from 7-day-old mice or rat pups, since granule cell neuronogenesis in the rodent cerebellum takes place postnatally from days P0-P15 (Solà et al. 2011). Once differentiated in vitro, these cells express proteins for vesicular and plasma transport of glutamate, and respond to depolarizing stimulus by releasing the neurotransmitter glutamate (Suñol et al. 2008, 2010; Fonfría et al. 2005; Babot et al. 2005; Briz and Suñol 2011). Postsynaptic events in primary cultures of cerebellar granule neurons are mainly due to activation of GABA and glutamate receptors whose functional expressions have been demonstrated by the binding of the specific radioligands $\left[{ }^{3} \mathrm{H}\right]$-GABA and $\left[{ }^{3} \mathrm{H}\right]$-muscimol, $\left[{ }^{3} \mathrm{H}\right]$-flunitrazepam, and $\left[{ }^{35} \mathrm{~S}\right]$ - $t$-butyl bicyclophosphorothionate (TBPS) at the GABA receptor (sites for recognition of GABA, benzodiazepine, and picrotoxinin, respectively)—(Pomés et al. 1993; Vale et al. 1997; Babot et al. 2007; Suñol and García 2011) - the binding of [ $\left.{ }^{3} \mathrm{H}\right]-\mathrm{MK}-801$ at the glutamate-NMDA receptor, and the immunolabeling of the NR1 subunit of the NMDA receptor (Babot et al. 2007; Briz and Suñol 2011). The functionality of the $\mathrm{GABA}_{\mathrm{A}}$ receptor in primary cultured neurons can be determined by measuring the ${ }^{36} \mathrm{Cl}^{-}$influx induced by GABA (Suñol and García 2011), and that of glutamate receptors by measuring the increase of intracellular calcium by means of fluorescent probes (Briz and Suñol 2011). Furthermore, the presence of the strychnine-sensitive glycine receptor has also been demonstrated in primary cultures of CGCs by measuring the ${ }^{36} \mathrm{Cl}^{-}$influx induced by glycine (Vale et al. 2003). Finally, cultured CGCs are highly vulnerable to oxidative stress, probably because of the low energy reserves and high intrinsic stress levels of these cells (Wang et al. 2009). Also to be noticed is that cultured CGCs express the estrogen receptors (ER) being enriched in $\mathrm{ER} \alpha$, which makes these cells also useful for the assessment of neuroestrogenic effects of endocrine disruptors (Briz et al. 2011).

In this chapter, we review some of our studies regarding the effects of $\mathrm{MeHg}$ on glutamatergic neurons. Both short- and long-term exposures of cultured cerebellar granule neurons to $\mathrm{MeHg}$ have been evaluated, trying to find clues for the mechanisms of $\mathrm{MeHg}$ neurotoxicity under acute or chronic exposure.

\section{Effects of Methylmercury on Presynaptic Glutamate Transport}

The uptake of glutamate in neurons and glia is a key event to protect neurons from excitotoxicity induced by excessive activation of glutamate receptors. Five glutamate transporters (EAAT) have been cloned so far, and they are highly dependent on the cellular red-ox status (Gegelashvili et al. 2001). When CGCs expressing the neuronal EAAT3 glutamate transporter were acutely exposed to $\mathrm{MeHg}$, the transport of glutamate (determined as $\left[{ }^{3} \mathrm{H}\right]$-aspartate uptake) was inhibited with an $\mathrm{IC}_{50}$ value of $12.5 \mu \mathrm{M}$ (Fonfría et al. 2005), similar to values found in astrocytes (Aschner 

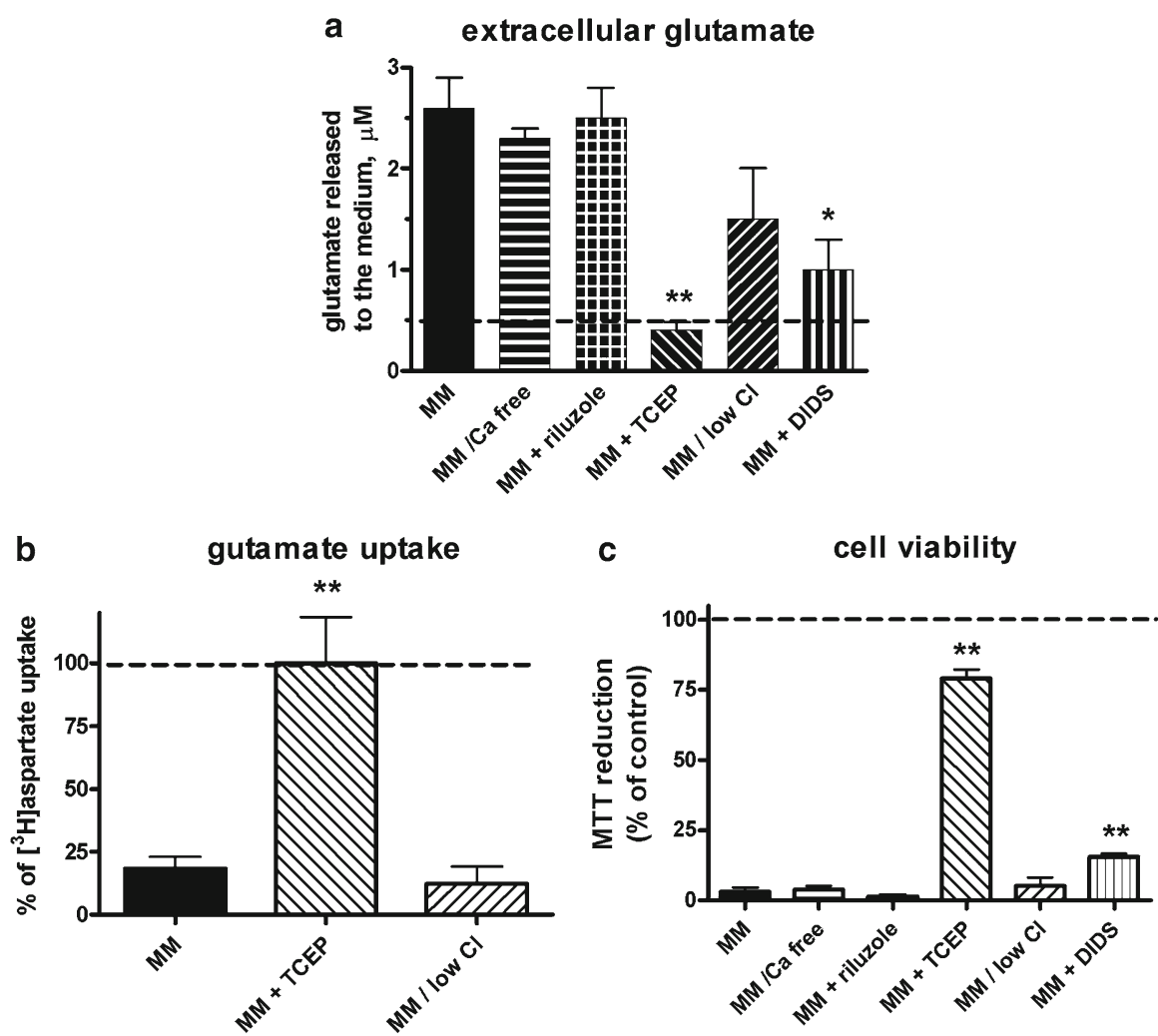

Fig. 14.1 Effects of $\mathrm{MeHg}$ on presynaptic glutamate neurotransmission and cell viability in primary cultures of cerebellar granule neurons. The cells were exposed to $30 \mu \mathrm{M} \mathrm{MeHg}$ for $10 \mathrm{~min}$ at $36^{\circ} \mathrm{C}$ in the absence (black bars) or in the presence of $0.5 \mathrm{mM}$ TCEP, $1 \mathrm{mM}$ DIDS, $0.1 \mathrm{mM}$ riluzole, low $\mathrm{Cl}^{-}$buffer, and free $\mathrm{Ca}^{2+}$ buffer. The dashed line indicates control values in the absence of MeHg. (a) Release of endogenous glutamate and accumulation in the extracellular space determined by HPLC. (b) Uptake of glutamate determined as $\left[{ }^{3} \mathrm{H}\right]$-aspartate. (c) Cell viability determined by the MTT assay measuring mitochondrial activity. Data are means \pm SEM of three experiments. $* p<0.05$ and ${ }^{* *} p<0.01$ vs. MeHg after significant one-way ANOVA (Redrawn from Fonfría et al. 2005)

et al. 1993; Allen et al. 2001). Likewise, exposure of CGCs to MeHg resulted in increased concentrations of extracellular glutamate eventually attaining toxic levels ( $>2 \mu \mathrm{M}$, Babot et al. 2005). It is well known that glutamate transporters function in the reversed direction, carrying glutamate from the cytoplasm to the extracellular space, under ischemic conditions when ATP production is decreased. Also, hyposmotic swelling activates efflux of taurine and other organic osmolytes such as glutamate through swelling-activated anion channels. The MeHg-induced release and extracellular accumulation of glutamate was reduced by TCEP (a non thiol reducing agent), by the $\mathrm{Cl}^{-}$channel blocker DIDS and by exposing the cells to a low $\mathrm{Cl}^{-}$ buffer, but not by riluzole (a compound that blocks electrically evoked glutamate release) or by the nominal absence of $\mathrm{Ca}^{2+}$ (Fig. 14.1a). On the other hand, TCEP 
reverted the effect of $\mathrm{MeHg}$ on $\left[{ }^{3} \mathrm{H}\right]$-aspartate uptake (Fig. 14.1b) and protected CGCs from MeHg-induced loss of mitochondrial activity (Fig. 14.1c) and ATP reduction (Fonfría et al. 2005). Our results suggest that both inhibition of glutamate transport and cell swelling contribute to the accumulation of extracellular glutamate induced by $\mathrm{MeHg}$.

Thereafter we exposed the cells to $\mathrm{MeHg}$ for 5-10 days in vitro. $\mathrm{MeHg}$-induced cell death was concentration- and time-dependent, with $\mathrm{LC}_{50}$ values of $508 \pm 199,345 \pm 47$, and $243 \pm 45 \mathrm{nM}$ after exposure for 6,11 , and 16 days in vitro, respectively ( $p=0.05$, one-way ANOVA) (Vendrell et al. 2010). Contrarily to the effects observed after short term and high concentration $(>1 \mu \mathrm{M})$ exposure to $\mathrm{MeHg}$, exposure to $100 \mathrm{nM} \mathrm{MeHg}$ for 10 days in vitro or to $300 \mathrm{nM} \mathrm{MeHg}$ for 5 days in vitro, which did not induce cell death, did not result in inhibition of the glutamate transport nor in changes of intracellular glutamate levels (Vendrell et al. 2007, 2010; Farina et al. 2009). All together these results suggest that impairment of neuronal glutamate homeostasis is a key event in the acute-high level toxicity of $\mathrm{MeHg}$, whereas other mechanisms underlie the cellular toxic effects of long-term and low-level exposure to $\mathrm{MeHg}$.

\section{Effects of Methylmercury on Postsynaptic Glutamate and $\mathrm{GABA}_{\mathrm{A}}$ Receptors}

Glutamatergic CGCs express a whole array of subunits for $\mathrm{GABA}_{\mathrm{A}}$ and glutamate receptors. Glutamate-induced excitotoxicity is mediated by activation of NMDA receptors and influx of calcium, eventually leading to cell death. Edwards et al. (2005) found that $\mathrm{MeHg}$ was much more toxic in cerebellar granule neurons than in cerebellar Purkinje neurons. Although the latest were devoid of functional NMDA receptors (Joels et al. 1989), both cerebellar cell types respond to $\mathrm{MeHg}$ exposure with an increase in intracellular calcium (Edwards et al. 2005). Significant increase of intracellular calcium in CGCs was achieved after short exposure ( $<30 \mathrm{~min}$ ) to micromolar concentrations of $\mathrm{MeHg}$, where calcium entry was mainly through voltage-gated calcium channels (VGCC) and the Na/Ca exchanger (Szücs et al. 1997; Gassó et al. 2001, Edwards et al. 2005). However, when CGCs were exposed to submicromolar concentrations of $\mathrm{MeHg}$ for extended periods of time (4 days in vitro), the intracellular calcium concentration remained unchanged (132 \pm 17 and $149 \pm 15 \mathrm{nM}$ in control and $300 \mathrm{nM} \mathrm{MeHg}$-exposed cells, respectively) (Farina et al. 2009). Since exposure of CGCs to $300 \mathrm{nM} \mathrm{MeHg}$ for 5 days in vitro resulted in loss of cell viability without earlier disruption in intracellular calcium homeostasis at 4 days in vitro, it is suggested that chronic $\mathrm{MeHg}$-induced neurotoxicity is not mediated by increased [Ca]i, whereas disruption in intracellular calcium homeostasis may underlie the acute neurotoxicity of $\mathrm{MeHg}$.

The $\mathrm{GABA}_{\mathrm{A}}$ receptor/ $\mathrm{Cl}^{-}$ionophore complex is an oligomeric protein that has separate but allosterically interacting binding sites for the endogenous neurotransmitter GABA, for benzodiazepines and for picrotoxinin-like convulsants. A wide spectrum of drugs, toxic agents and metals modify the $\mathrm{GABA}_{\mathrm{A}}$ receptor function by directly interacting with or allosterically modulating these binding sites. 
Contradictory effects have been reported for the effects of mercury compounds on the $\mathrm{GABA}_{\mathrm{A}}$ receptor $\left(\mathrm{GABA}_{\mathrm{A}} \mathrm{R}\right)$. First Narahashi et al. (1994) reported that mercuric chloride augmented the GABA-induced current $\left(\mathrm{Cl}^{-}\right.$influx) whereas $\mathrm{MeHg}$ suppressed the GABA-induced current in dorsal root ganglion neurons. A dual effect was observed for $\mathrm{HgCl}_{2}$ in hippocampal cultures, first increasing $\mathrm{GABA}_{\mathrm{A}}$-mediated $\mathrm{Cl}^{-}$flux before suppressing it, suggesting that $\mathrm{HgCl}_{2}$ may initially increase the open probability of GABA-activated chloride channels (Yuan and Atchison 1997). In this line, we have reported that short exposure to $\mathrm{HgCl}_{2}$ or $\mathrm{MeHg}$ increased the binding of $\left[{ }^{3} \mathrm{H}\right]$-flunitrazepam to the benzodiazepine recognition site $\left(\mathrm{EC}_{50}\right.$ values were 3.6 and $15.2 \mu \mathrm{M}$ for $\mathrm{HgCl}_{2}$ and $\mathrm{MeHg}$, respectively) in cultured CGCs (Fonfría et al. 2001). This effect was time-dependent for $\mathrm{MeHg}$, like it has been reported for the reduction of GABA-mediated currents (Herden et al. 2008), but not for $\mathrm{HgCl}_{2}$. The increase of $\left[{ }^{3} \mathrm{H}\right]$-flunitrazepam binding was mimicked by the sulfhydryl alkylating agent $N$-ethylmaleimide and inhibited by $\mathrm{GABA}_{\mathrm{A}}$ receptor antagonists and the anion transporter blocker DIDS. However, changes in intracellular calcium, kinase activation/inactivation or antioxidant conditions did not modify the effects of mercury compounds on the $\mathrm{GABA}_{A} \mathrm{R}$. Whether the effects of $\mathrm{MeHg}$ on the GABA $\mathrm{R}$ are directly mediated by the way of alkylation of SH groups of cysteinyl residues found in $\mathrm{GABA}_{\mathrm{A}}$ receptor subunit sequences needs further research. Despite of the acute effects of $\mathrm{MeHg}$ on the $\mathrm{GABA}_{\mathrm{A}} \mathrm{R}$, not much attention has been paid to its effects after chronic exposure. A study of the effects of several developmental neurotoxicants on mRNA levels of several neural markers reveals that prolonged exposure of CGCs to $50 \mathrm{nM} \mathrm{MeHg}$ resulted in a significant downregulation of the $\mathrm{GABA}_{\mathrm{A}} \mathrm{R}$ mRNA, this effect being produced at a time where other neural markers were unchanged (Hogberg et al. 2010). These results are in agreement with the recent finding that $\left[{ }^{3} \mathrm{H}\right]$-muscimol binding at the GABA $\mathrm{R}$ was significantly decreased in the cerebellum following dietary exposure of mink to $\mathrm{MeHg}$ (Basu et al. 2010).

\section{Effect of Methylmercury on Cellular Red-Ox Homeostasis}

The generation of ROS such as superoxide anion, hydrogen peroxide, and peroxy and hydroxyl radicals can be produced by the action of toxic insults or due to normal metabolic processes such as the mitochondrial electron transport chain. Under normal physiological conditions, intracellular enzymes such as $\mathrm{Cu} / \mathrm{Zn}$ superoxide dismutase (SOD), glutathione peroxidase (GPx), and catalase prevent the formation/accumulation of ROS. The overproduction of oxidants and/or the decline of cell endogenous antioxidant defenses by exposure to toxic compounds results in the induction of oxidative stress damaging the major biological macromolecules such as nucleic acids, proteins, lipids, and carbohydrates, which eventually produces cell death. In addition, some neuronal functions are affected by the induction of oxidative stress in the absence of cell death, including the mechanisms mediated by glutamate transporters and NMDA and GABA receptors (Lipton et al. 2002).

ROS generation caused by short exposure to micromolar concentrations of $\mathrm{MeHg}$ was reduced by the antioxidants probucol and propyl gallate, which eventually 
a
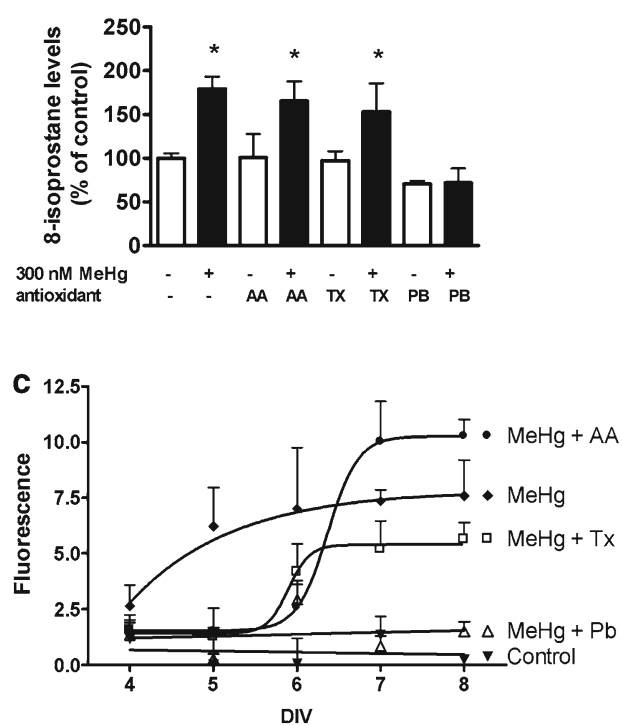
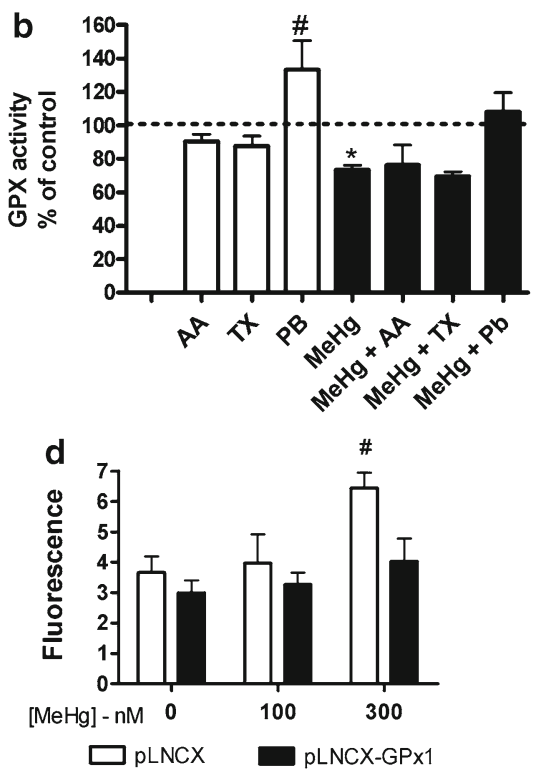

Fig. 14.2 MeHg-induced lipid peroxidation and cell death in primary cultures of cerebellar granule neurons is mediated by inhibition of glutathione peroxidase (GPx). The cells were exposed to $300 \mathrm{nM} \mathrm{MeHg}$ in the absence and in the presence of the antioxidants probucol (PB), ascorbic acid (AA), or trolox (Tx). (a) Lipid peroxidation was determined by measuring 8-isoprostane levels after exposing the cells to $\mathrm{MeHg}$ and antioxidants from day in vitro 1 to day in vitro 5. (b) Probucol returned GPx activity to control values after exposure to MeHg, an effect not shared by AA nor Tx. (c) MeHg-induced cytotoxicity (diamond), as determined by the increased fluorescence of incorporated propidium iodide, was completely abolished by probucol (triangle), whereas AA (filled circle) and trolox (unfilled square) only offered time-limited protection. (d) Overexpression of GPx-1 in primary cultures of cerebellar granule cells (black bars) offered protection against $\mathrm{MeHg}$ induced cytotoxicity (Adapted from Farina et al. 2009 with permission)

reduced MeHg-induced cell death in cerebellar granule neurons (Gassó et al. 2001). Prolonged exposure of CGCs to submicromolar concentrations of MeHg also resulted in oxidative stress inducing lipid peroxidation (Fig. 14.2a) and increasing cell vulnerability against peroxides such as hydrogen peroxide and t-butyl hydroxy peroxide (Vendrell et al. 2007; Farina et al. 2009). The analysis of endogenous regulators of red-ox homeostasis revealed that reduction of GPx activity was the first event induced by prolonged exposure to low $\mathrm{MeHg}$ concentration before changes in glutathione (GSH), catalase and glutathione reductase (GR) could be observed (Farina et al. 2009). In agreement, GPx inhibition and lipid peroxidation were found to occur earlier than GSH and GR changes in animals prenatally exposed to MeHg (Carvalho et al. 2007; Stringari et al. 2008). Probucol increased GPx activity by itself and inhibited $\mathrm{MeHg}$-induced lipid peroxidation, whereas the antioxidants ascorbic acid and trolox did not (Fig. 14.2b). Accordingly, probucol elicited long-lasting protection against MeHg-induced cellular toxicity, while ascorbic acid and trolox had a timelimited protecting effect (Fig. 14.2c). It has been recently reported that MeHg induces the degradation of GPx-1mRNA by nonsense-mediated mRNA decay, this effect 
being observed earlier than it was the incidence of oxidative stress (Usuki et al. 2011). It is noteworthy that overexpression of GPx-1 in cultured CGCs prevented MeHg-induced neuronal death (Fig. 14.2d) (Farina et al. 2009). GPx is a selenohydrylcontaining enzyme and the selenohydryl group has higher affinity than the thiol group for MeHg (Sugiura et al. 1978). Carvalho et al. (2008) reported that mercury exhibited selective inhibition on TrxR (a thiol- and seleno-protein) over GR (a thiolprotein) in lysates of HeLa cells. Accordingly, it has been recently reported that TrxR activity in the brain of zebra fish was inhibited after $\mathrm{MeHg}$ exposure, whereas GR activity was not (Branco et al. 2011).

\section{Effects of Methylmercury on Cytoskeleton}

Cell death induced by low $\mathrm{MeHg}$ concentrations is through an apoptotic pathway that is accompanied by neurite beading and microtubule fragmentation long before nuclear condensation occurred (Castoldi et al. 2000; Vendrell et al. 2007). A proteomic study of CGCs exposed to low concentrations of $\mathrm{MeHg}(\leq 1 \mu \mathrm{M})$ for several days revealed both a decrease in the phosphorylation of the cytosolic protein cofilin and the translocation of cofilin from the cytosol to the mitochondria (Fig. 14.3) (Vendrell et al. 2010). The balance of cofilin phosphorylation/nonphosphorylation forms regulates actin dynamics and facilitates actin filament turnover, which are responsible for neuron shape change, migration, polarity formation and regulation of synaptic structures and function. Cofilin is phosphorylated at serine 3 by LIM

a

$060100 \mathrm{nM}$ b

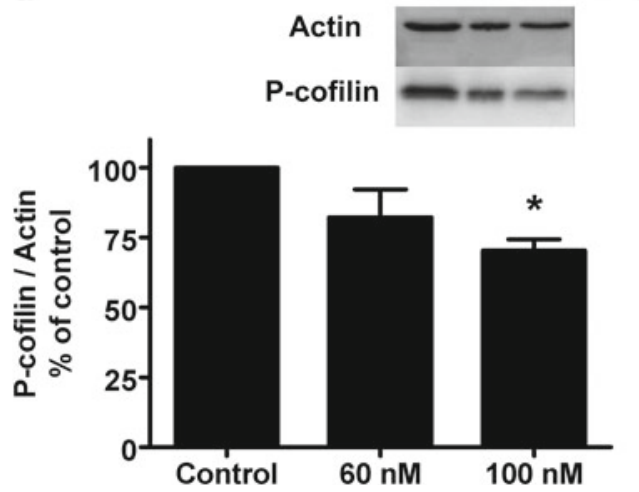

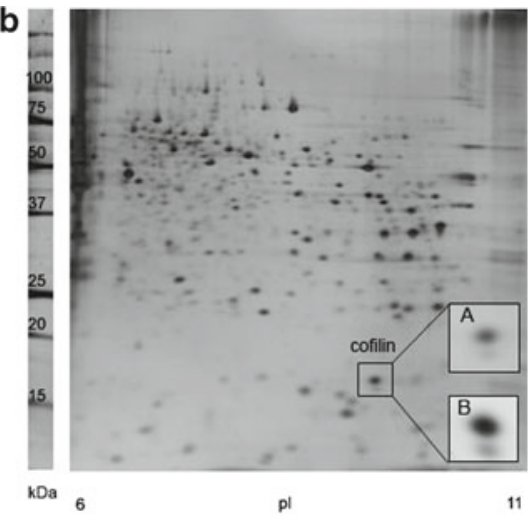

Fig 14.3 (a) Decrease of P-cofilin expression in homogenates of primary cultures of cerebellar granule cells exposed to $0-100 \mathrm{nM}$ methylmercury up to 11-14 days in vitro. (b) Representative 2DE map of a mitochondrial-enriched protein extract from primary cultures of mouse cerebellar granule cells. Insets are representative images of the cofilin spot corresponding to control and $60 \mathrm{nM} \mathrm{MeHg}$-treated cells (A and $\mathbf{B}$, respectively) showing the increased expression of nonphosphorylated cofilin in the mitochondria of cultured cerebellar granule cells (Adapted from Vendrell et al. 2010 with permission) 
kinases (LIMK), which in turn are activated by the Rho family of small GTPases (Rho/ROCK). In this line, Fujimura et al. $(2009,2011)$ reported the downregulation of the Rho-family proteins $\mathrm{Rac1}$ and $\mathrm{Cdc} 42$ in the early stages of $\mathrm{MeHg}$-induced cytotoxicity and the prevention of MeHg-induced toxicity in vivo and in vitro by inhibiting the Rho/ROCK pathway. On the other hand, cofilin has been reported to translocate to the mitochondria prior to the release of cytochrome c, as an early step in apoptosis (Chua et al. 2003). Mitochondria contain proapoptotic elements such as cytochrome $\mathrm{c}$ and the apoptosis-inducing factor (AIF), which are released after MeHg exposure (Fonfría et al. 2002; Tamm et al. 2006). MeHg-induced toxicity was evidenced as axonal degeneration and apoptotic neuronal cell death in both cultured cortical neurons and CGCs, and as loss of neurons, axonal degeneration, and vacuolar degeneration in the spinal cord of intoxicated rats (Castoldi et al. 2000; Fujimura et al. 2009, 2011). Therefore, an alteration of the complex regulation of the cofilin phosphorylation/dephosphorylation pathway could be envisaged as an underlying mechanism compatible with reported signs of $\mathrm{MeHg}$-induced neurotoxicity. The fact that the increased expression of nonphosphorylated cofilin both in cell homogenates and in mitochondria was observed after exposure to a subcytotoxic concentration of MeHg (Vendrell et al. 2010) suggests that cofilin phosphorylation/dephosphorylation pathways may be early markers of $\mathrm{MeHg}$ induced neurotoxicity.

Acknowledgments This research was supported by grants from the Spanish Ministries of Health and of Science and Innovation (PI 061212, PI 10/0453) and the Generalitat of Catalunya (2009/ SGR/214).

\section{References}

Allen JW, Mutkus LA, Aschner M. Methylmercury-mediated inhibition of 3H-D-aspartate transport in cultured astrocytes is reversed by the antioxidant catalase. Brain Res. 2001;902: 92-100.

Aschner M, Du YL, Gannon M, Kimelberg HK. Methylmercury-induced alterations in excitatory amino acid transport in rat primary astrocyte cultures. Brain Res. 1993;602:181-6.

Babot Z, Cristòfol RM, Suñol C. Excitotoxic death induced by released glutamate in depolarised primary cultures of mouse cerebellar granule cells is dependent on $\mathrm{GABA}_{\mathrm{A}}$ receptors and niflumic acid-sensitive chloride channels. Eur J Neurosci. 2005;21:103-12.

Babot Z, Vilaró MT, Suñol C. Long-term exposure to dieldrin reduces GABA and NMDA receptor function in primary cultures of mouse cerebellar granule cells. J Neurosci Res. 2007;85: 3687-95.

Basu N, Scheuhammer AM, Rouvinen-Watt K, Evans RD, Trudeau VL, Chan LHM. In vitro and whole animal evidence that methylmercury disrupts GABAergic systems in discrete brain regions in captive mink. Comp Biochem Physiol C. 2010;151:379-85.

Branco V, Canário J, Holmgren A, Carvalho C. Inhibition of the thioredoxin system in the brain and liver of zebra-seabreams exposed to waterborne methylmercury. Toxicol Appl Pharmacol. 2011;251:95-103.

Briz V, Suñol C. Homeostatic regulation of glutamate neurotransmission in primary neuronal cultures (Chap. 17). In: Costa LG, Giordano G, Guizzetti M, editors. In vitro neurotoxicology. Methods and protocols, Methods in molecular biology, vol. 758. 2011. pp. 253-65. 
Briz V, Molina-Molina JM, Sánchez-Redondo S, Fernández MF, Grimalt JO, Olea N, RodríguezFarré E, Suñol C. Differential estrogenic effects of the persistent organochlorine pesticides dieldrin, endosulfan and lindane in primary neuronal cultures. Toxicol Sci. 2011;120:413-27.

Carvalho MC, Franco JL, Ghizoni H, Kobus K, Nazari EM, Rocha JBT, Nogueira CW, Dafre AL, Müller YML, Farina M. Effects of 2,3-dimercapto-1-propanesulfonic acid (DMPS) on methylmercury-induced locomotor deficits and cerebellar toxicity in mice. Toxicology. 2007;239:195-203.

Carvalho CML, Chew EH, Hashemy SI, Lu J, Holmgren A. Inhibition of the human thioredoxin system. A molecular mechanism of mercury toxicity. J Biol Chem. 2008;283:11913-23.

Castoldi AF, Barni S, Turin I, Gandini C, Manzo L. Early acute necrosis, delayed apoptosis and cytoskeletal breakdown in cultured cerebellar granule neurons exposed to methylmercury. J Neurosci Res. 2000;59:775-87.

Castoldi AF, Coccini T, Manzo L. Neurotoxic and molecular effects of methylmercury in humans. Rev Environ Health. 2003;18:19-31.

Choi BH, Lapham LW, Amin-Zaki L, Saleem T. Abnormal neuronal migration, deranged cerebral cortical organization, and diffuse white matter astrocytosis of human fetal brain: a major effect of methylmercury poisoning in utero. J Neuropathol Exp Neurol. 1978;37:719-33.

Chua BT, Volbracht C, Tan KO, Li R, Yu VC, Li P. Mitochondrial translocation of cofilin is an early step in apoptosis induction. Nat Cell Biol. 2003;5:1083-9.

Clarkson TW, Magos L, Myers GJ. The toxicology of mercury-current exposures and clinical manifestations. New Engl J Med. 2003;349:1731-7.

Edwards JR, Marty MS, Atchison WD. Comparative sensitivity of rat cerebellar neurons to dysregulation of divalent cation homeostasis and cytotoxicity caused by methylmercury. Toxicol Appl Pharmacol. 2005;208:222-32.

Ekino S, Susa M, Ninomiya T, Imamura K, Kitamura T. Minamata disease revisited: an update on the acute and chronic manifestations of methyl mercury poisoning. J Neurol Sci. 2007;262: 131-44.

Eto K, Marumoto M, Takeya M. The pathology of methylmercury poisoning (Minamata disease). Neuropathology. 2010;30:471-9.

Farina M, Campos F, Vendrell I, Berenguer J, Barzi M, Pons S, Suñol C. Probucol increases glutathione peroxidase-1 activity and displays long-lasting protection against methylmercury toxicity in cerebellar granule cells. Toxicol Sci. 2009;112:416-26.

Fonfría E, Rodríguez-Farré E, Suñol C. Mercury interaction with the $\mathrm{GABA}_{\mathrm{A}}$ receptor modulates the benzodiazepine binding site in primary cultures of cerebellar granule cells. Neuropharmacology. 2001;41:819-33.

Fonfría E, Dare E, Benelli M, Suñol C, Ceccatelli S. Translocation of apoptosis inducing factor in cerebellar granule cells exposed to neurotoxic agents inducing oxidative stress. Eur J Neurosci. 2002;16:2013-6.

Fonfría E, Vilaró MT, Babot Z, Rodríguez-Farré E, Suñol C. Mercury compounds disrupt neuronal glutamate transport in cultured mouse cerebellar granule cells. J Neurosci Res. 2005;79: $545-53$.

Fujimura M, Usuki F, Sawada M, Rostene W, Godefroy D, Takashima A. Methylmercury exposure downregulates the expression of Racl and leads to neuritic degeneration and ultimately apoptosis in cerebrocortical neurons. Neurotoxicology. 2009;30:16-22.

Fujimura M, Usuki F, Kawamura M, Izumo S. Inhibition of the Rho/ROCK pathway prevents neuronal degeneration in vitro and in vivo following methylmercury exposure. Toxicol Appl Pharmacol. 2011;250:1-9.

Gassó S, Cristòfol RM, Selema G, Rosa R, Rodríguez-Farré E, Sanfeliu C. Antioxidant compounds and $\mathrm{Ca}^{2+}$ pathway blockers differentially protect against methylmercury and mercuric chloride neurotoxicity. J Neurosci Res. 2001;66:135-45.

Gegelashvili G, Robinson MB, Trotti D, Rauen T. Regulation of glutamate transporters in health and disease. Prog Brain Res. 2001;32:267-86.

Grandjean P, Landrigan PJ. Developmental neurotoxicity of industrial chemicals. Lancet 2006; 368:2167-78.

Grandjean P. Methylmercury toxicity and functional programming. Reprod Toxicol. 2007;23: 414-20. 
Herden CJ, Pardo NE, Hajela RK, Yuan Y, Atchison WD. Differential effects of methylmercury on gamma-aminobutyric acid type A receptor currents in rat cerebellar granule and cerebral cortical neurons in culture. J Pharmacol Exper Ther. 2008;324:517-28.

Hogberg HT, Kinsner-Ovaskainen A, Coecke S, Hartung T, Bal-Price AK. mRNA expression is a relevant tool to identify developmental neurotoxicants using an in vitro approach. Toxicol Sci. 2010;113:95-115.

Joels M, Yoolt AJ, Gruol DL. Unique properties of non-N-methyl-D-aspartate excitatory responses in cultured Purkinje neurons. Proc Natl Acad Sci USA. 1989;86:3404-8.

Korogi Y, Takahashi M, Okajima T, Eto K. MR findings of Minamata disease-organic mercury poisoning. J Magn Reson Imaging. 1998;8:308-16.

Lipton SA, Choi YB, Takahashi H, Zhang D, Li W, Godzik A, Bankston LA. Cysteine regulation of protein function-as exemplified by NMDA-receptor modulation. Trends Neurosci. 2002;25:474-80.

Murata K, Grandjean P, Dakeishi M. Neurophysiological evidence of methylmercury neurotoxicity. Am J Ind Med. 2007;50:765-71.

Narahashi T, Ma JY, Arakawa O, Reuveny E, Nakahiro M. GABA receptor-channel complex as a target site of mercury, copper, zinc, and lanthanides. Cell Mol Neurobiol. 1994;14:599-621.

Pomés A, Rodríguez-Farré E, Suñol C. Inhibition of $t-\left[{ }^{35} \mathrm{~S}\right]$ butylbicyclophosphorothionate binding by convulsant agents in primary cultures of cerebellar neurons. Brain Res Dev Brain Res. 1993;73:85-90.

Ramón R, Murcia M, Ballester F, Rebagliato M, Lacasaña M, Vioque J, Llop S, Amurrio A, Aguinagalde X, Marco A, León G, Ibarluzea J, Ribas-Fitó N. Prenatal exposure to mercury in a prospective mother-infant cohort study in a Mediterranean area, Valencia, Spain. Sci Total Environ. 2008;392(1):69-78.

Sanfeliu C, Sebastià J, Cristòfol R, Rodríguez-Farré E. Neurotoxicity of organomercurial compounds. Neurotox Res. 2003;5:283-305.

Solà C, Cristòfol R, Suñol C, Sanfeliu C. Primary cultures for neurotoxicity testing (Chap. 4). In: Aschner M, Suñol C, Bal-Price A, editors. Cell culture techniques, Neuromethods, vol. 56. 2011. pp. 87-103.

Stringari J, Nunes AKC, Franco JL, Bohrer D, Garcia SC, Dafre AL, Milatovic D, Souza DO, Rocha JBT, Aschner M, Farina M. Prenatal methylmercury exposure hampers glutathione antioxidant system ontogenesis and causes long-lasting oxidative stress in the mouse brain. Toxicol Appl Pharmacol. 2008;227:147-54.

Sugiura Y, Tamai Y, Tanaka H. Selenium protection against mercury toxicity; high binding affinity of methylmercury by selenium-containing ligands in comparison with sulfur-containing ligands. Bioinorg Chem. 1978;9:167-80.

Suñol C, García DA. GABA receptor binding and ion channel function in primary neuronal cultures for neuropharmacology/neurotoxicity testing (Chap. 25). In: Aschner M, Suñol C, BalPrice A, editors. Cell culture techniques, Neuromethods, vol. 56. 2011. pp. 481-93.

Suñol C, Babot Z, Fonfría E, Galofré M, García D, Herrera N, Iraola S, Vendrell I. Studies with neuronal cells: from basic studies of mechanisms of neurotoxicity to the prediction of chemical toxicity. Toxicol In Vitro. 2008;22:1350-5.

Suñol C, Babot Z, Cristòfol R, Sonnewald U, Waagepetersen HS, Schousboe A. A possible role of the non-GAT1 GABA transporters in transfer of GABA from GABAergic to glutamatergic neurons in mouse cerebellar neuronal cultures. Neurochem Res. 2010;35:1384-90.

Szücs A, Angiello C, Salánki J, Carpenter DO. Effects of inorganic mercury and methylmercury on the ionic currents of cultured rat hippocampal neurons. Cell Mol Neurobiol. 1997;17:273-88.

Tamm C, Duckworth J, Hermanson O, Ceccatelli S. High susceptibility of neural stem cells to methylmercury toxicity: effects on cell survival and neuronal differentiation. J Neurochem. 2006;97:69-78.

US National Academy of Sciences. Toxicity Testing in the 21st Century: A Vision and a Strategy. Washington (USA): The National Acad. Press; 2007.

Usuki F, Yamashita A, Fujimura M. Post-transcriptional defects of antioxidant selenoenzymes cause oxidative stress under methylmercury exposure. J Biol Chem. 2011;286:6641-9. 
Vale C, Pomés A, Rodríguez-Farré E, Suñol C. Allosteric interactions between GABA, benzodiazepine and picrotoxinin binding sites in primary cultures of cerebellar granule cells. Differential effects induced by $\gamma$ - and $\delta$-hexachlorocyclohexane. Eur J Pharmacol. 1997;319:343-53.

Vale C, Fonfría E, Bujons J, Messeguer A, Rodríguez-Farré E, Suñol C. The organochlorine pesticides $\gamma$-hexachlorocyclohexane (lindane) and the cyclodienes $\alpha$-endosulfan and dieldrin differentially interact with $\mathrm{GABA}_{\mathrm{A}}$ and glycine- gated chloride channels in primary cultures of cerebellar granule cells. Neuroscience. 2003;117:397-402.

Vendrell I, Carrascal M, Vilaró MT, Abián J, Rodríguez-Farré E, Suñol C. Cell viability and proteomic analysis in cultured neurons exposed to methylmercury. Hum Exp Toxicol. 2007;26: 263-72.

Vendrell I, Carrascal M, Campos F, Abián J, Suñol C. Methylmercury disrupts the balance between phosphorylated and non-phosphorylated cofilin in primary cultures of mice cerebellar granule cells. A proteomic study. Toxicol Appl Pharmacol. 2010;242:109-18.

Wang X, Zaidi A, Pal R, Garrett AS, Braceras R, Chen X, Michaelis ML, Michaelis EK. Genomic and biochemical approaches in the discovery of mechanisms for selective neuronal vulnerability to oxidative stress. BMC Neurosci. 2009;10:12. doi:10.1186/1471-2202-10-12.

Yorifuji T, Tsuda T, Inoue S, Takao S, Harada M. Long-term exposure to methylmercury and psychiatric symptoms in residents of Minamata, Japan. Environ Int. 2011;37:907-13.

Yuan Y, Atchison WD. Action of methylmercury on GABA $\mathrm{A}_{\mathrm{A}}$ receptor-mediated inhibitory synaptic transmission is primarily responsible for its early stimulatory effects on hippocampal CA1 excitatory synaptic transmission. J Pharmacol Exper Ther. 1997;282:64-73. 